N. Tran

B. Dao

\title{
Thermal Analysis of the SSC Beam Scraper
}

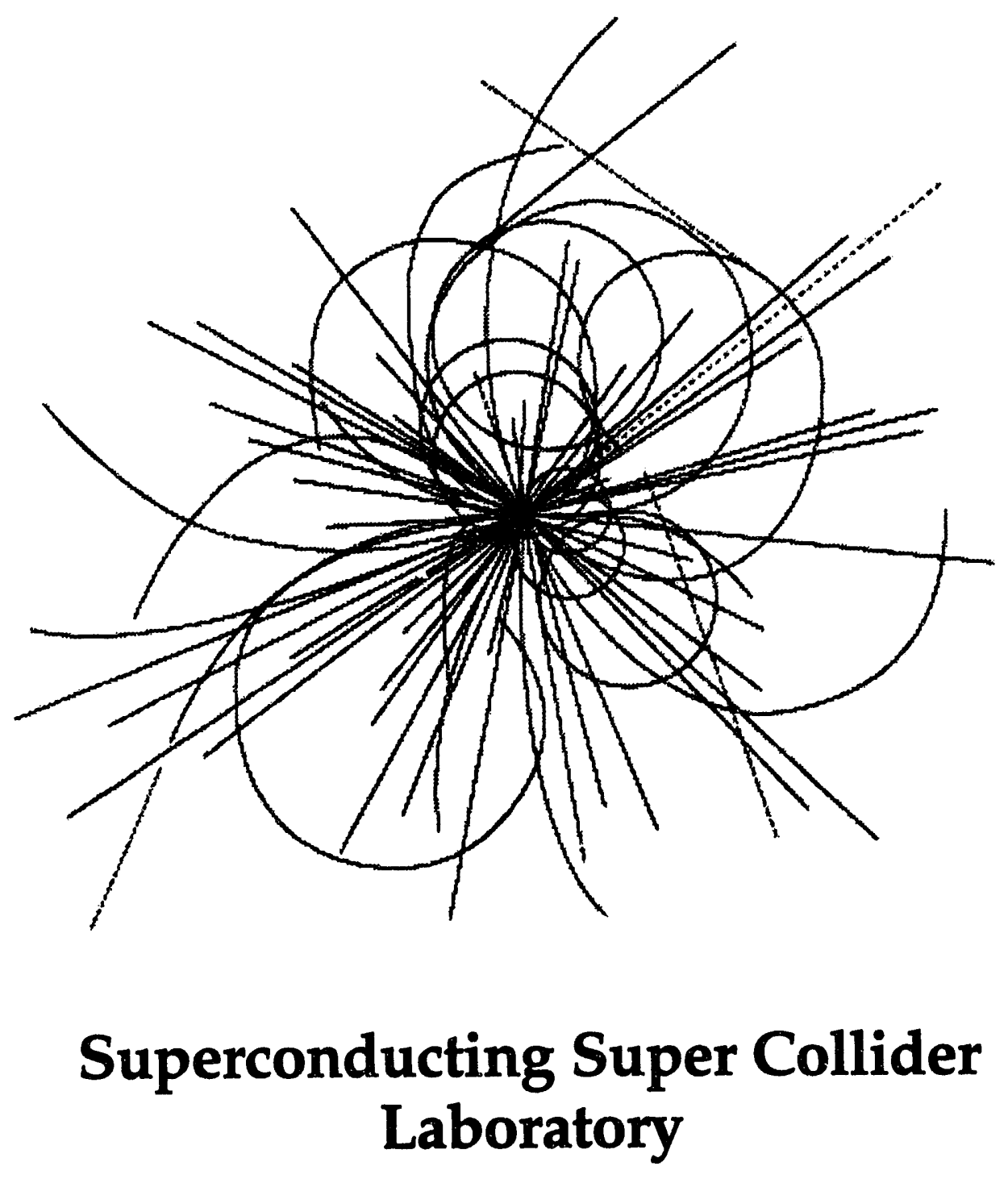

COEIVED

JUN 011993

OSTI 
Disclaimer Notice

This report was prepared as an account of work sponsored by an agency of the United States Government. Noither the United States Govemment of any agency thereof, nor any of their employess, makes any warrenty, express or implied, or asesumes any legal liability or responsibility for the sccumcy, completeness, of usefulness of any intormation, apparatus, product, of processe diectoesd, or represents that he ues would not intringe privately owned rights. Roterence herein to any specific commercial product, processs, or service by trade name, trademark, manulecturer, or Othenwas, does not necesaurily conetitute or imply ths endoreement, recommendation, or favoring by the United States Govemment or any agency thereot. The views and opinions of authors expresesed herein do not necsesearly state or reflect thoes of the United States Covernment or any eqency thereot.

Superconducting Super Collider Laboratory is an equal opportunity employer. 


\title{
Thermal Analysis of the SSC Beam Scraper*
}

\author{
N. Tran and B. Dao \\ Superconducting Super Collider Laboratory ${ }^{\dagger}$ \\ 2550 Beckleymeade Ave. \\ Dallas, TX 75237
}

April 1993

"Presented at the Fifth Annual International Symposium on the Super Collider, May 6-8, 1993 San Francisco, CA. tOperated by the Universities Research Association, Inc., for the U.S. Department of Energy under Contract No. DE-AC35-89ER40486. 


\title{
THERMAL ANALYSIS OF THE SSC BEAM SCRAPER
}

\author{
N. Tran and B. Dao \\ Mechanical Engineering Department \\ Accelerator Systems Division \\ Superconducting Super Collider Laboratory* \\ 2550 Beckleymeade Avenue, MS 4006 \\ Dallas, TX 75237-3997
}

\begin{abstract}
When a particle beam impacts a beam scraper, heat is generated resulting in a rise in the temperature of the material. The maximum temperature rise should be kept to a minimum in order to maintain scraper efficiency and performance. In this paper the results of a thermal analysis of a scraper are presented.
\end{abstract}

\section{INTRODUCTION}

Beam scrapers are devices, located in the West Utility region of the collider rings, for removing the unwanted, diffused halo of particles that surrounds the dense central core of the accelerated beam $^{1}$. It is important to minimize the peak scraper temperature to avoid excessive thermal deflection in a lateral direction on scraping surface. As indicated in Figure 1, three main scraper designs, using copper material, were evaluated from a thermal viewpoint. The first design involves no effort to cool the scraper. The second involves solid cooling while the third design adds water cooling.

\section{ANALYSIS}

A transient, three dimensional finite element model was developed using ANSYS ${ }^{2}$. The temperature dependent thermo-physical properties of copper were accounted for. The scraper initial temperature was assumed to be $305 \mathrm{~K}$ for all the analyses. Load boundary conditions included a constant scraping rate of about $1.45 \times 10^{9}$ protons per second ${ }^{3}$ resulting in about 1284 watts applied for 20 minutes. Figures 2 and 3 show the energy deposition density per proton along the longitudinal and lateral directions of a copper scraper ${ }^{4}$. Radiation effects were omitted and an adiabatic condition was assumed on the scraper outside surfaces. Based on these analyses, an optimum scraper design can be chosen.

- Operated by the Universities Research Association, Inc., for the U.S. Department of Energy under Contract No. DE-AC35-89ER40486. 


\section{RESULTS}

Table 1 shows the thermal analyses results associated with three different scraper design concepts. A temperature rise was significantly reduced almost $400 \mathrm{~K}$ from a baseline (case 1) to a solid cooling (case 2) and improved even further with a water cooling design (cases 3,4 and 5).

\section{CONCLUSION}

Based on the present thermal analysis, a water cooled scraper gives the lowest peak temperature after 20 minutes at full scraping rate.

\section{REFERENCES}

1. Element Specification (Level 3B), Collider Accelerator Arc Sections, Superconducting Super Collider Laboratory (SSCL), Number E10-000027, August, (1992).

2. ANSYS Engineering Analysis System, Revision 4.4, Swanson Analysis Systems, Inc., Houston, Pennsylvania, (1989).

3. Discussion with R. Soundranayagam.

4. M. Maslov, N. Mokhov, and I. Yazynin, "The SSC Beam Scraper System," SSCL -484, June, (1991).

\begin{tabular}{|c|c|c|c|}
\hline $\begin{array}{l}\text { Case } \\
\text { No. }\end{array}$ & \multicolumn{2}{|c|}{ Description } & $\underset{(\mathrm{K})}{\Delta \mathrm{T}_{\max }}$ \\
\hline 1 & \multicolumn{2}{|c|}{ Baseline design with $1^{n} \times 2^{n} \times 47^{\prime \prime}$ copper rod } & 456 \\
\hline 2 & \multicolumn{2}{|c|}{ Solid cooling with 6 " Dia $\times 47^{\prime \prime}$ copper block, $2^{\prime \prime}$ scraping surfaces } & 54 \\
\hline 3 & \multirow{3}{*}{$\begin{array}{l}\text { Solid and water cooling with two } \\
1 / 2^{\prime \prime} \text { Dia. water channels spacing } \\
1 \text { " from scraping surface }\end{array}$} & 2 liters/min. per channel & 27 \\
\hline 4 & & 5 liters/min. per channel & 20 \\
\hline 5 & & 10 liters/min. per channel & 17 \\
\hline
\end{tabular}

Table 1. Peak scraper temperatures for different design concepts (after 20 minutes).

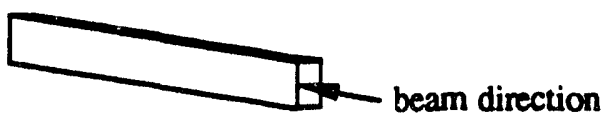

(a)

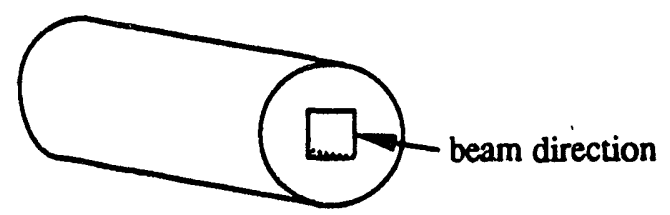

(b)

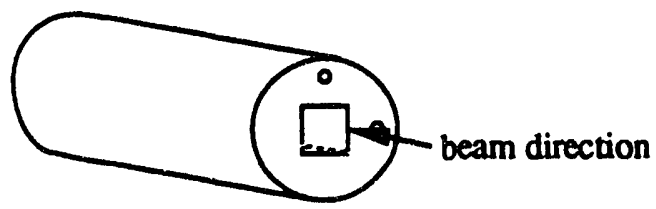

(c)

Figure 1. Schematic of the SSC beam scraper with different design concepts: (a) baseline design, (b) solid cooling, and (c) solid and water cooling. 


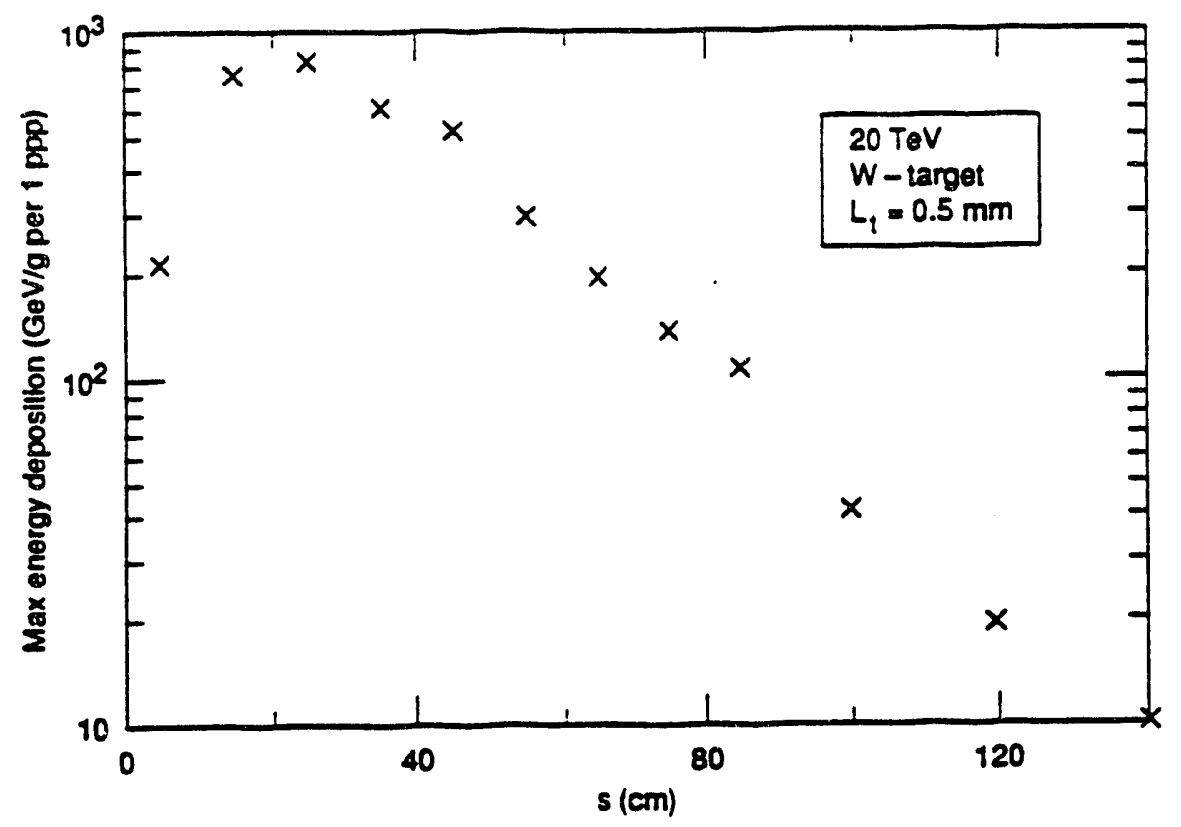

Figure 2. Longitudinal distribution of maximum energy deposition density in the copper seraper for chosen parameters of the scraper system.

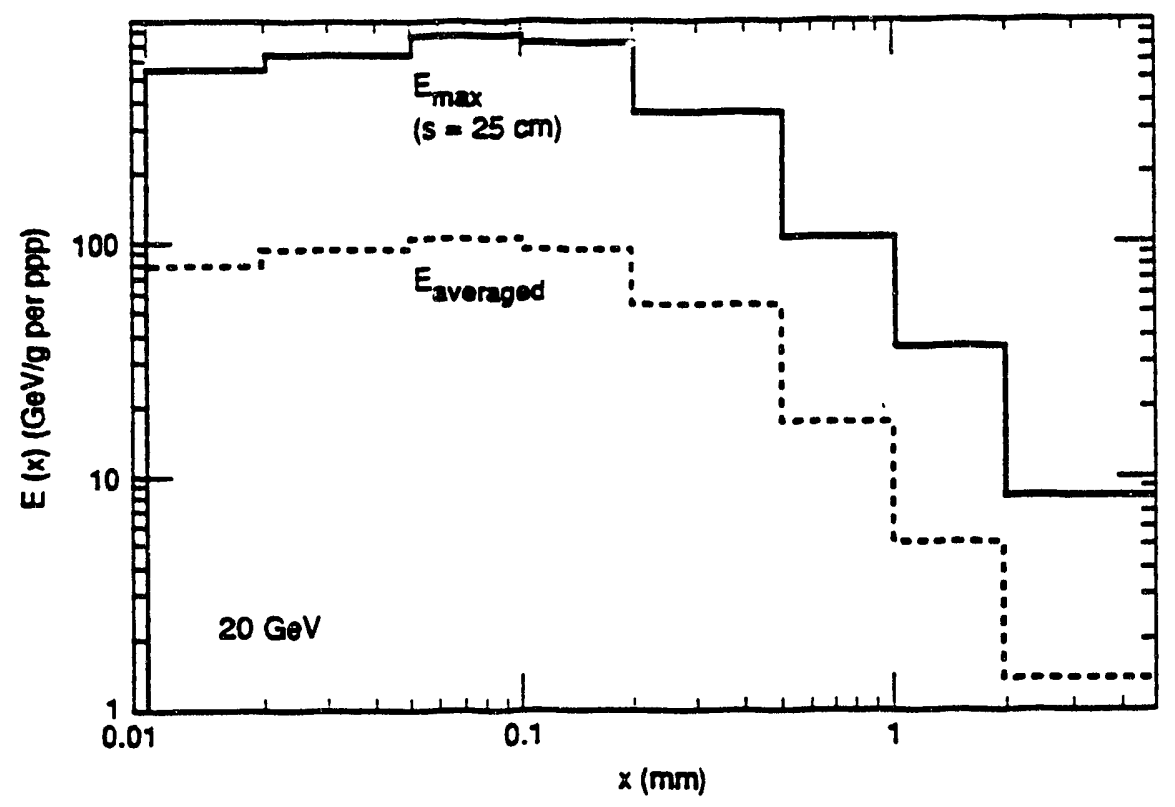

Figure 3. Lateral distribution of energy deposition in the copper seraper at shower maximum and averaged over $120 \mathrm{~cm}$ of length. 


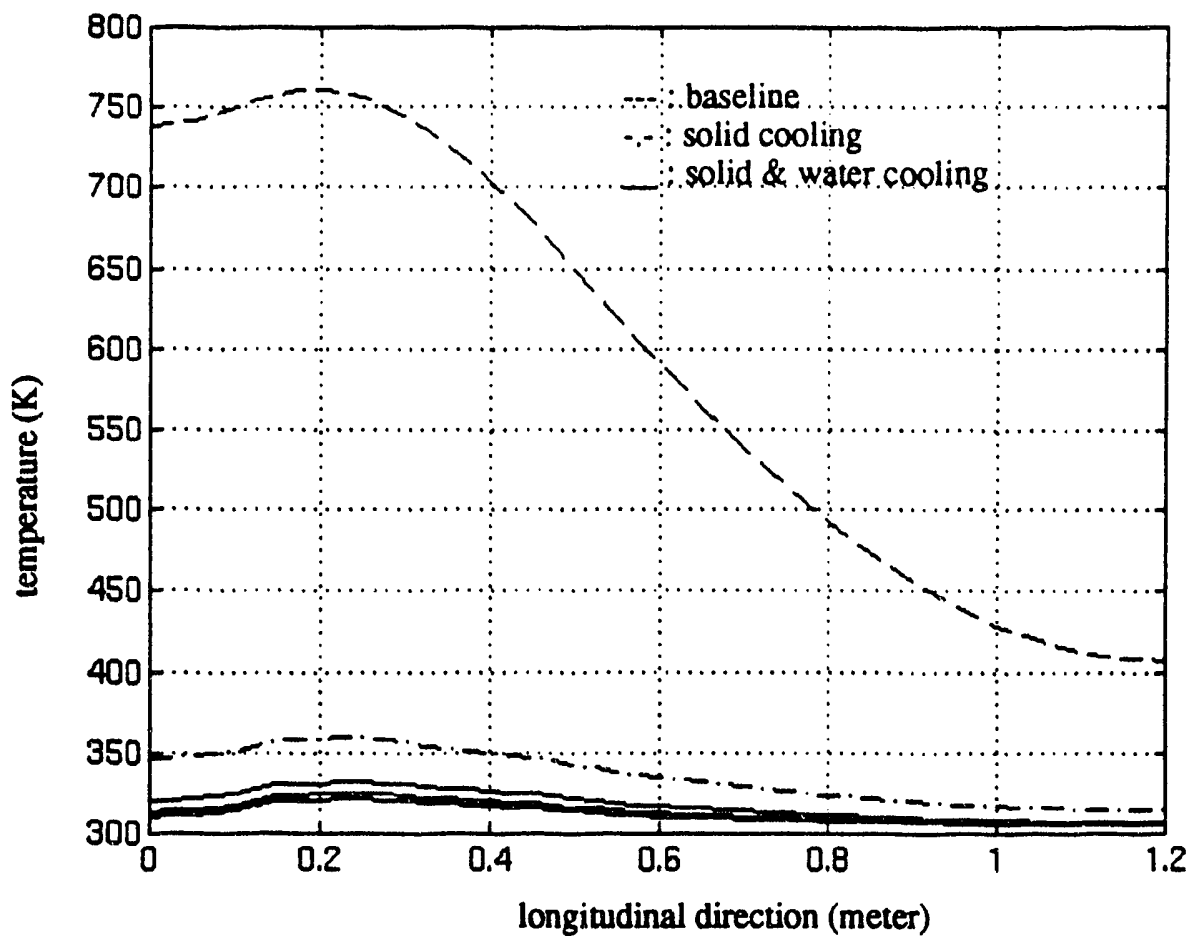

Figure 4. Variation of temperature on scraping surface along scraper length for the three design concepts.

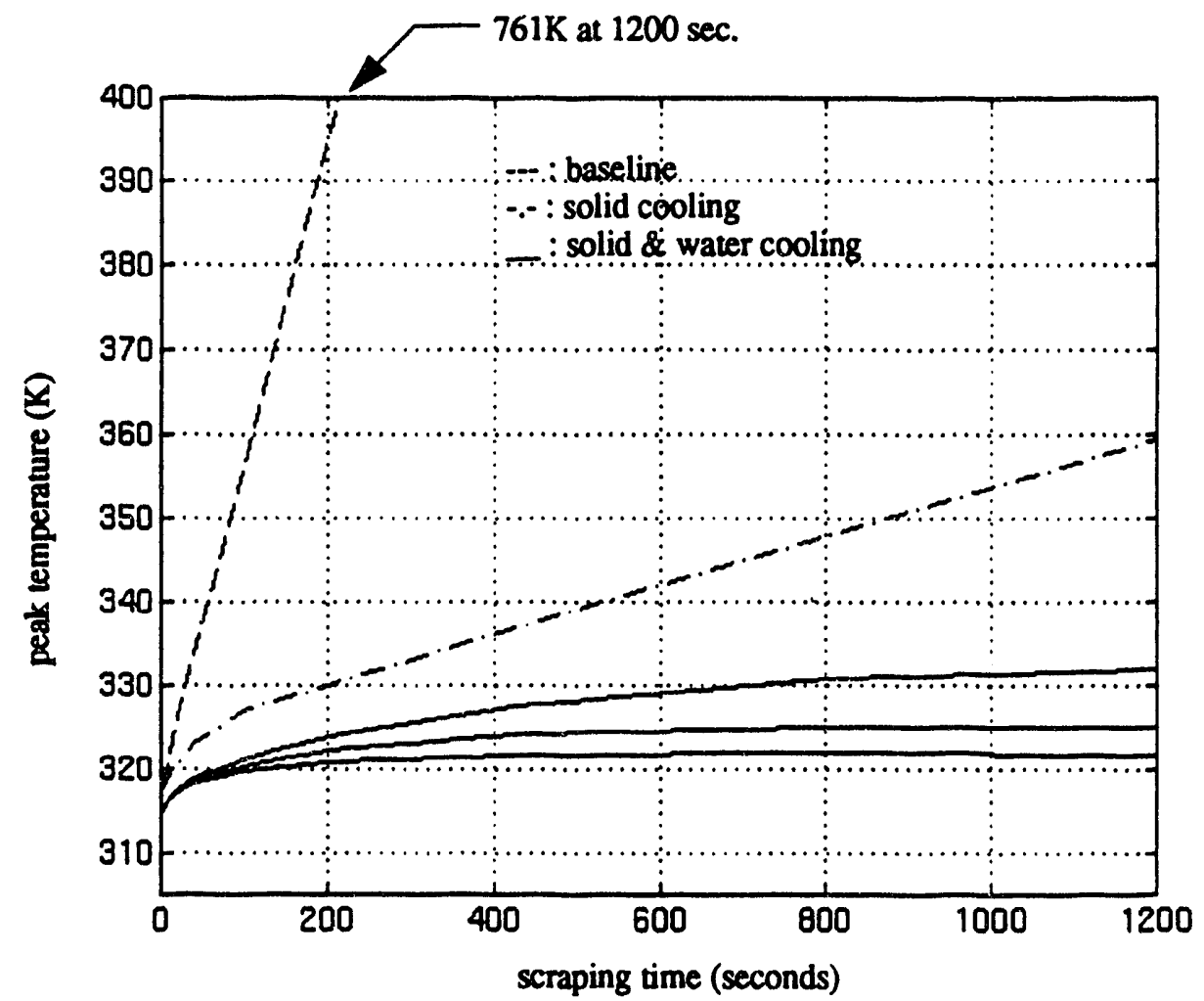

Figure 5. Variation of scraper peak temperature with time for the three design concepts. 

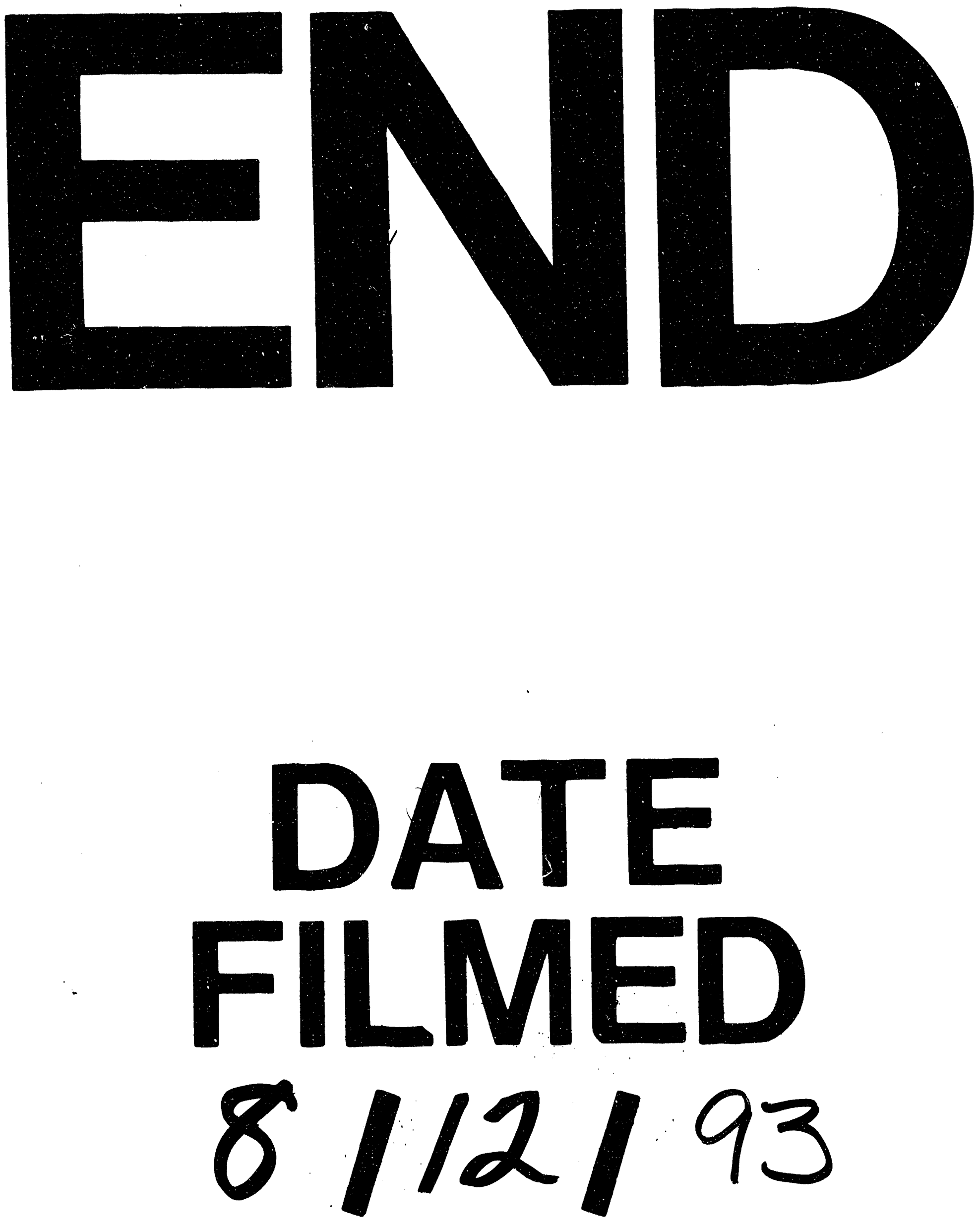
